\title{
RAPID RESTORATION OF A SPECIES-RICH ECOSYSTEM ASSESSED FROM SOIL AND VEGETATION INDICATORS: THE CASE OF CALCAREOUS GRASSLANDS RESTORED FROM FOREST STANDS.
}

Julien Piqueray ${ }^{1}$, Gaëtan Bottin ${ }^{1}$, Louis-Marie Delescaille ${ }^{2}$, Emmanuelle Bisteau ${ }^{1}$, Gilles Colinet $^{3}$, Grégory Mahy ${ }^{1}$.

${ }^{1}$ University of Liege, Gembloux Agro-Bio Tech, Laboratory of Ecology. 2, Passage des Déportés B-5030 Gembloux. Belgium.

2 Service Public de Wallonie - DGARNE, Département de l'Etude du Milieu naturel et agricole. 23, Avenue Maréchal Juin B-5030 Gembloux. Belgium.

${ }^{3}$ University of Liege, Gembloux Agro-Bio Tech, Laboratory of Geopedology. 2, Passage des Déportés B-5030 Gembloux. Belgium.

Ecological Indicators 11, 724-733 (2011)

Postprint version at http://www.sciencedirect.com/science/journal/1470160X 


\begin{abstract}
Calcareous grasslands have long been recognized as biodiversity hotspots in Europe. However, in recent decades these ecosystems have seen rapid decline. In Belgium, more than 100 ha of calcareous grasslands have been restored from oak coppices and pine forests since the 1990s. The aim of the present study was to provide a quantitative assessment of the success of these restoration efforts, using two sets of indicators: one related to soil conditions, the other related to vascular plant communities. Soil conditions were evaluated by comparing soil samples from pre-restoration forest stands, restored grasslands (3 age classes: 2-4 years; 5-8 years, 10-15 years) and reference grasslands. The analysis revealed no significant differences in soil $N$, $P$ and $K$ contents between pre-restoration forests and restored and reference grasslands. We observed a decrease in the mineralization rate indicators in both pre-restoration forests and recent grassland restorations, which was resorbed in older restorations. Floristic surveys revealed that plant species composition of older restorations was most like reference grasslands. However, some differences in species composition persisted after 15 years. Moreover, a few rare species did not colonise restored grasslands despite a close seed source. Non-recolonization by a set of species expected on calcareous grasslands may be due to dispersal limitation and higher cover by native invasive grasses in restored parcels. These results were discussed in term of implications for management.
\end{abstract}




\section{Introduction}

In the face of destruction and fragmentation of natural and semi-natural habitats, protection and management of the remaining (semi-) natural habitat fragments is no longer sufficient to ensure the long-term viability of all elements contributing to biodiversity. Consequently, habitat restoration has become a necessity to recreate functional ecological networks (Jongman \& Pungetti 2004). This approach serves to restore patches of degraded or destroyed habitat by accelerating or skipping successional stages. This is accomplished by directing ecosystem development towards a specific community structure or ecosystem type (Bakker \& Berendse 1999; Jordan et al. 1987). However, habitat restoration can be cost prohibitive and efforts to restore natural communities must demonstrate their success in reaching target ecosystems (Fagan et al. 2008). Hence, quantitative indicators are needed to evaluate the efficiency of restoration practices and to improve future restoration projects (e.g. Holl \& Cairns 2002; Samu et al. 2008). Ideally, these indicators may address different components of the restored ecosystem.

Habitat restoration is of vital importance in temperate semi-natural calcareous grasslands, and has received considerable attention in recent years. Those ecosystems are considered one of the richest in biodiversity in temperate regions (Prendergast et al. 1993; WallisDeVries et al. 2002) and the most species-rich plant communities in the world at a small scale ( $\left.<10 \mathrm{~m}^{2}\right)$ (Willems 2001). Once widespread over Europe, calcareous grasslands have undergone dramatic fragmentation since the end of the nineteenth century. Following the abandonment of the traditional agro-pastoral systems that were responsible for their extension, these communities have been replaced by arable land, trees plantations, or have undergone spontaneous encroachment and succession to forest communities (Poschlod \& WallisDeVries 2002). The maintenance and enhancement of calcareous grassland networks is now recognized as a priority in European biodiversity conservation policies, as reflected in the Habitat Directive 92/43/EEC.

Restoration success depends primarily on two factors, the reformation and maintenance of suitable environmental conditions and the recolonization capacity of target species (Perrow \& Davy 2002; Piqueray \& Mahy 2009). Soil conditions in calcareous grasslands are characterized by low soil fertility, and nutrient transfer historically occurred through traditional grazing practices (Willems 2001). A negative relationship between soil fertility and calcareous grasslands species richness has been demonstrated (e.g. Al-Mufti et al. 1977; Janssens et al. 1998) as well as the harmful consequences of intentional soil nutrient enrichment (Bobbink et al. 1998; Jacquemyn et al. 2003; Willems et al. 1993). On arable lands, attempts to restore soils to historically low fertility levels was shown to be the major constraint for the recovery of calcareous grassland plant communities (Hutchings \& Stewart 2002; Walker et al. 2004). However, to our knowledge, soil nutrient status has never been studied in calcareous grasslands restored from forest stands. Green (1972) stressed that natural succession should lead to global eutrophication of any habitat. Hurst and John (1999) showed nitrogen enrichment in calcareous 
grassland during the first step of encroachment by the native invasive grass Brachypodium pinnatum in England. Data from other grassland types indicate that afforestation can induce different changes in soil conditions. On one hand, it often induces a reallocation of major nutrients (N, P) from mineral soil to litter (Farley \& Kelly 2004; Ross et al. 1999), as well as changes in the form of these nutrients (Chen et al. 2008; Farley \& Kelly 2004). After clearcutting, litter decomposition can increase the nutrient release (Ouro et al. 2001). On the other hand, shrub and tree colonization can induce modifications to the soil micro-climate, and subsequently cause changes in soil microbial activity responsible for the mineralization of soil organic matter. This can lead to modifications in soil carbon stock, acidity and $C: N$ ratio (Thuille \& Schulze 2006). Therefore, we argue that mineralization indicators (e.g. $\mathrm{pH}, \mathrm{C}: \mathrm{N} \mathrm{ratio}$, and $\mathrm{Fe}$ ), as well as fertility indicators (e.g. N, P, and K) need to be considered to assess the restoration of soil conditions. Decreasing $\mathrm{pH}$ and subsequent increasing Fe availability could be consequences of a lower mineralization rate (Bonneau \& Souchier 1979).

In plant community recovery efforts, species richness has been widely used as an indicator of restoration efficiency (e.g. Cristofoli et al. 2009: Lindborg \& Eriksson 2004; Willems 2001). However, it is only a crude indicator of successful restoration (Kiehl et al. 2006; Mortimer et al. 1998). An ecosystem may be species-rich, but the species may be non-representative of the native community. Therefore, restoration success should be evaluated against a reference habitat, such as a local reference site (Piqueray \& Mahy 2009; Ruiz-Jaen \& Aide 2005; Society for Ecological Restoration International Science \& Policy Working Group 2004).

In Belgium, over $90 \%$ of calcareous grasslands have been lost (Adriaens et al. 2006; Bisteau \& Mahy 2005a). A large proportion were afforested with Pinus sylvestris and $P$. nigra at the end of the $19^{\text {th }}$ century (Vandermotten \& Decroly 1995). Other areas experienced a natural process of succession following grazing abandonment and were progressively replaced by oak woodlands. To stop this decline, approximately 100 ha of calcareous grasslands have been restored in Belgium over the last 15 years. All restored sites derived from pre-forests or 40100 year old forest established on ancient calcareous grasslands. Restoration protocols included tree and shrub clearing followed by sheep and goat grazing (André \& Vandendorpel 2004; Graux 2004). Restoration of species-rich grasslands from secondary forest or pre-forest ecosystems was studied in different parts of Europe (Kiefer \& Poschlod 1996; Pärtel et al. 1998; Zobel et al. 1996), but rarely in Western Europe (Hutchings \& Stewart 2002).

In this paper we combined soil condition and plant community data with the aim of assessing the success of calcareous grasslands restoration from afforested sites in Belgium. Using indicators computed from these two datasets, we compared restored sites with calcareous grassland reference sites and forest stands equivalent to pre-restoration conditions and addressed the following questions: 1) Do restoration actions lead to the reestablishment of native calcareous grassland plant communities; 2) How does soil of restored sites compare to soil of reference grasslands and pre-restoration sites? 


\section{Material and Methods}

\section{Study sites}

The study area was located in two Belgian regions: the Viroin Valley, and the Lesse and Lomme Valleys (Table 1), both located in Calestienne, a narrow Devonian limestone strip running southwest to northeast. Both regions support large areas of calcareous grasslands, and are considered the core areas for calcareous grassland conservation in Belgium. Although several grassland communities occurred within the study area (see Butaye et al. (2005) and Piqueray et al. (2007) for communities description), we focused on the most widespread community: Mesobromion calcareous grasslands. A total of 12 sites (six per region) where grassland restoration had occurred were selected for the study (Table 1). Selected sites were restored half from pine stands and half from oak coppices. Pine stands were up to 100 -year-old Pinus nigra or P. sylvestris plantations. Dense shrub oak coppices were mainly formed with Prunus spinosa, Crataegus monogyna and Corylus avellana, with intermingled scarce trees of Quercus robur. Historical maps, aerial pictures and field surveys were used to delimit three parcel types: 1) reference grasslands, i.e. calcareous grasslands known to have existed for more than two centuries. They harbour the typical local calcareous grassland vegetation and are considered as the reference ecosystem for restoration. 2) restored parcels, i.e. former grasslands that were afforested and were then subject to forest clearings with subsequent management (mainly grazing) with the aim of restoring grasslands. Trees and shrubs were exported from the parcels, but tree stumps remained. 3) pre-restoration forest stands, i.e. forests established on former calcareous grasslands. Both reference grasslands and pre-restoration forest stands were adjacent to restored parcels, on similar topographic situations. The time passed since restoration (in years) was known for each restored parcel. Restored parcels were chosen to equally cover three age classes since restoration: 2-4 years, 5-8 years and 10-15 years. These classes were mainly defined due to field constraints, e.a. first year was omitted as many uncertainties remained on the location of last clearcuts location at the beginning of our project. Each site comprised at least one parcel of each type. In the "Tienne des Vignes" and "Montagne au Buis" sites, two restored parcels originated from the same forest stand but were restored at different times, these restored parcels had thus the same reference forest stands and reference grasslands. In addition, at "Les Pairées" and "Abannets" sites, two restored parcels were of the same age but originated from two different forest stands (Pine and Oak). In summary, we sampled 8 pre-restoration forests parcels, 12 restored parcels (four per age class) and 8 reference grassland parcels (Table 1 ). 
Table 1: Sampled parcels in the study region, name of the site and age classes (forests are pre-restoration forests; grasslands are reference grasslands). Forest type and age since restoration are respectively given for pre-restoration forests and restored parcels.

\begin{tabular}{|c|c|c|c|c|c|}
\hline Name & Localisation & Region & Age class & Forest stand & Real age \\
\hline Tienne des Vignes & $5^{\circ} 06^{\prime} \mathrm{N}-5^{\circ} 10^{\prime} \mathrm{E}$ & Lesse and Lomme & Forest & Pine & 1 \\
\hline Lorinchamps & $50^{\circ} 06^{\prime} \mathrm{N}-5^{\circ} 14^{\prime} \mathrm{E}$ & Lesse and Lomme & Forest & Oak & l \\
\hline Tienne d'Aize & $50^{\circ} 07^{\prime} \mathrm{N}-5^{\circ} 09^{\prime} \mathrm{E}$ & Lesse and Lomme & Forest & Oak & l \\
\hline Les Pairées & $50^{\circ} 06^{\prime} \mathrm{N}-5^{\circ} 11^{\prime} \mathrm{E}$ & Lesse and Lomme & Forest & Pine/Oak & l \\
\hline Niémont & $50^{\circ} 06^{\prime} \mathrm{N}-4^{\circ} 42^{\prime} \mathrm{E}$ & Viroin & Forest & Pine & l \\
\hline Montagne-aux-Buis & $50^{\circ} 05^{\prime} \mathrm{N}-4^{\circ} 34^{\prime} \mathrm{E}$ & Viroin & Forest & Oak & l \\
\hline Rivelottes & $50^{\circ} 05^{\prime} 30^{\prime \prime} \mathrm{N}-4^{\circ} 40^{\prime} \mathrm{E}$ & Viroin & Forest & Pine & / \\
\hline Abannets & $50^{\circ} 04^{\prime} 30^{\prime \prime} \mathrm{N}-4^{\circ} 34^{\prime} \mathrm{E}$ & Viroin & Forest & Pine/Oak & l \\
\hline Tienne des Vignes & $50^{\circ} 06^{\prime} \mathrm{N}-5^{\circ} 10^{\prime} \mathrm{E}$ & Lesse and Lomme & $2-4$ years & 1 & 2 years \\
\hline Lorinchamps & $50^{\circ} 06^{\prime} \mathrm{N}-5^{\circ} 14^{\prime} \mathrm{E}$ & Lesse and Lomme & $2-4$ years & 1 & 2 years \\
\hline Tienne des Vignes & $50^{\circ} 06^{\prime} \mathrm{N}-5^{\circ} 10^{\prime} \mathrm{E}$ & Lesse and Lomme & $5-8$ years & l & 8 years \\
\hline Tienne d'Aize & $50^{\circ} 07^{\prime} \mathrm{N}-5^{\circ} 09^{\prime} \mathrm{E}$ & Lesse and Lomme & 5-8 years & 1 & 8 years \\
\hline Les Pairées pine & $50^{\circ} 06^{\prime} \mathrm{N}-5^{\circ} 11^{\prime} \mathrm{E}$ & Lesse and Lomme & $10-15$ years & l & 10 years \\
\hline Les Pairées oak & $50^{\circ} 06^{\prime} \mathrm{N}-5^{\circ} 11^{\prime} \mathrm{E}$ & Lesse and Lomme & $10-15$ years & l & 10 years \\
\hline Niémont & $50^{\circ} 06^{\prime} \mathrm{N}-4^{\circ} 42^{\prime} \mathrm{E}$ & Viroin & 2-4 years & 1 & 2 years \\
\hline Montagne-aux-Buis North & $50^{\circ} 05^{\prime} \mathrm{N}-4^{\circ} 34^{\prime} \mathrm{E}$ & Viroin & $2-4$ years & / & 4 years \\
\hline Rivelottes & $50^{\circ} 05^{\prime} 30^{\prime \prime} \mathrm{N}-4^{\circ} 40^{\prime} \mathrm{E}$ & Viroin & $5-8$ years & l & 5 years \\
\hline Montagne-aux-Buis South & $50^{\circ} 05^{\prime} 30^{\prime \prime} \mathrm{N}-4^{\circ} 34^{\prime} \mathrm{E}$ & Viroin & 5-8 years & l & 7 years \\
\hline Abannets pine & $50^{\circ} 04^{\prime} 30^{\prime \prime} \mathrm{N}-4^{\circ} 34^{\prime} \mathrm{E}$ & Viroin & $10-15$ years & / & 15 years \\
\hline Abannets oak & $50^{\circ} 04^{\prime} 30^{\prime \prime} \mathrm{N}-4^{\circ} 34^{\prime} \mathrm{E}$ & Viroin & $10-15$ years & 1 & 15 years \\
\hline Tienne des Vignes & $5^{\circ} 06^{\prime} \mathrm{N}-5^{\circ} 10^{\prime} \mathrm{E}$ & Lesse and Lomme & Grassland & / & 1 \\
\hline Lorinchamps & $50^{\circ} 06^{\prime} \mathrm{N}-5^{\circ} 14^{\prime} \mathrm{E}$ & Lesse and Lomme & Grassland & / & 1 \\
\hline Tienne d'Aize & $50^{\circ} 07^{\prime} \mathrm{N}-5^{\circ} 09^{\prime} \mathrm{E}$ & Lesse and Lomme & Grassland & l & l \\
\hline Les Pairées & $50^{\circ} 06^{\prime} \mathrm{N}-5^{\circ} 11^{\prime} \mathrm{E}$ & Lesse and Lomme & Grassland & l & 1 \\
\hline Niémont & $50^{\circ} 06^{\prime} \mathrm{N}-4^{\circ} 42^{\prime} \mathrm{E}$ & Viroin & Grassland & 1 & 1 \\
\hline Montagne-aux-Buis & $50^{\circ} 05^{\prime} \mathrm{N}-4^{\circ} 34^{\prime} \mathrm{E}$ & Viroin & Grassland & l & l \\
\hline Rivelottes & $50^{\circ} 05^{\prime} 30^{\prime \prime} \mathrm{N}-4^{\circ} 40^{\prime} \mathrm{E}$ & Viroin & Grassland & l & l \\
\hline Abannets & $50^{\circ} 04^{\prime} 30^{\prime \prime} \mathrm{N}-4^{\circ} 34^{\prime} \mathrm{E}$ & Viroin & Grassland & 1 & 1 \\
\hline
\end{tabular}

\section{Soil analysis}

Five soil samples were collected in each parcel, i.e. pre-restoration forests, restored parcels, and reference grasslands. Each sample consisted of a bulk soil sample collected systematically with a $2 \mathrm{~cm}$ diameter auger within a $1 \mathrm{~m}^{2}$ quadrat. The minimum total soil volume collected was $100 \mathrm{~cm}^{3}$ per quadrat. The soil was thin at all study sites (circa $10 \mathrm{~cm}$ ); therefore the entire soil layer, from ground surface to bedrock, was collected. Soil depth was measured at the four corners of the quadrat. Mean soil depth was estimated for each soil sample. In forests and reference grasslands, quadrats were randomly localized. In restored grasslands, samples were collected nearby randomly selected tree stumps. Positioning quadrats in the close vicinity of tree stumps ensured that the sample was not situated in a small remnant of the former grassland. Soil samples were sieved ( $<2 \mathrm{~mm}$ and one fraction $<0.5 \mathrm{~mm}$ ) after air-drying.

Total nitrogen content was estimated following the modified protocol of the Kjeldahl method described by Bremner \& Mulvaney (1982). Available phosphorus was determined using a modified version of Olsen \& Sommers (1982). Phosphorus was extracted by shaking $5 \mathrm{~g}$ of soil with $100 \mathrm{ml}$ of $0.5 \mathrm{~N} \mathrm{NaHCO}_{3}$, at pH of 8.5, for 30 minutes. Carbon black was added to clear 
filtrates. After filtering, a $5 \mathrm{ml}$ aliquot of extracted phosphorus was diluted in a $100 \mathrm{ml}$ volumetric flask with $10 \mathrm{ml} 1.5 \%\left(\mathrm{NH}_{4}\right)_{6} \mathrm{Mo}_{7} \mathrm{O}_{24} .4 \mathrm{H}_{2} \mathrm{O}$ and distilled water. The sample was coloured blue by adding $0.5 \mathrm{ml}$ of $1 \% \mathrm{SnCl}_{2}$, and phosphorus content was measured by spectrophotometry at $560 \mathrm{~nm}$. Total organic content was measured following the Springer-Klee method, i.e. a hot sample oxidation with $\mathrm{K}_{2} \mathrm{Cr}_{2} \mathrm{O}_{7}$ and titration of oxidant excess with $0.1 \mathrm{~N}$ $\left(\mathrm{NH}_{4}\right)_{2} \mathrm{Fe}\left(\mathrm{SO}_{4}\right)_{2} \cdot 6 \mathrm{H}_{2} \mathrm{O}$. Mobilizable fractions of $\mathrm{K}$ and $\mathrm{Fe}$ were determined after extraction with $1 \mathrm{~N} \mathrm{CH}_{3} \mathrm{COONH}_{4}-\mathrm{EDTA}$. The soil: solution ratio was $1: 5$, and the extraction solution $\mathrm{pH}$ was buffered at 4.65. Elements were measured in the remaining extraction solution by ICP-OES (VARIAN Vista MPX). Soil pH was estimated with a Hellige $\mathrm{pH}$-indicator.

A preliminary data analysis (results not shown) indicated variation among sites with significant mean differences for all soil variables. To reduce site effect, and to assess the effect of restoration as a function of the reference ecosystem, i.e. reference grasslands, soil data were transformed as follows:

$$
x_{i j}=x_{0, i j}-x_{\text {ref }, j}
$$

where $X_{i j}$ is the transformed value of the considered soil parameter in quadrat $i$ in site $j$, $X_{0, i j}$ is the initial value of the soil parameter in quadrat $i$ in site $j$, and $X_{\text {ref, }, j}$, is the mean value of the soil parameter over all quadrats of the reference grassland in site $\mathrm{j}$. In order to avoid pseudo-replication the average soil values of each parcel were considered for analyses.

We computed MANOVA (Wilks'lambda) in order to test for an overall difference among mean transformed value for the different soil parameters among the different types of parcels: pre-restoration forests, restored parcels of different ages (three classes) and reference grasslands. Thereafter, single response of each soil parameter was tested with a one-way ANOVA followed by post-hoc Fisher pairwise comparisons tests. By definition, the mean value for reference grasslands was zero. A canonical discriminant analysis was computed in order to illustrate patterns of variation in soil conditions among parcel types.

\section{Floristic analysis}

Floristic surveys and species cover (\%) were recorded in 20 quadrats $\left(1 \mathrm{~m}^{2}\right)$ in each restored parcel. Quadrats were located on cardinal directions one meter away from five randomly selected tree stumps. In addition, eighty quadrats were sampled in the reference grasslands and eighty other in pre-restoration forests (equally distributed among regions and then among grasslands/forests of each region). Only herbaceous and shrub species ( $<2 \mathrm{~m}$ height) were considered. Species cover values were log-transformed for analyses. In order to avoid pseudo-replication the average species cover of each parcel were considered for analyses.

Detrended Correspondence Analysis (DCA) was performed to examine similarities in species composition among parcels (reference grasslands, restored parcels of different age 
classes, i.e. 2-4 years, 5-8 years and 10-15 years, pre-restoration forests). We computed an Multiple Response Permutation Procedure (MRPP) with 10000 permutations in order to compare Bray-Curtis distances between and within age classes. In case of significant test, pairwise comparison of age classes was peformed. We tested if plant species composition differed among parcel types by identifying indicator species using the indicator value method INDVAL (Dufrêne \& Legendre 1997). Significant indicator species were detected for each parcel type following 999 Monte Carlo permutations, at $P=0.05$. In order to compare plant community structure from a more ecological perspective, species were classified into five ecological groups based on phytosociological alliances (Bisteau \& Mahy 2005b) : (1) species of calcareous grasslands (characteristic of the Festuco-Brometea or Sedo-Scleranthetea), that was divided in two subgroups: native invasive grass species (NIG) (Brachypodium pinnatum and Bromus erectus) and other grassland species; (2) ruderal species (i.e. characteristic of the Artemisietea, Plantaginetea and Epilobietea); (3) meadow species (characteristic of the MolinioArrhenatheretea); (4) edge species (characteristic of the Trifolio-Geranietea); and (5) woodlands and forest species (characteristic of the Querco-Fagetea). Shrubs were considered separately. Mean values for species richness, species evenness, shrub cover, bare ground cover and total cover of species belonging to each ecological groups (in \%) were compared among parcel types with one-way ANOVAs followed by post-hoc Fisher pairwise comparisons tests. Shrub cover, bare ground cover, edge species cover, other grassland species cover and ruderal species cover were log-transformed, and grassland species cover and forest species cover were Asintransformed to improve normality and homoscedasticity.

Finally, canonical correspondence analysis (CCA) was used to assess the influence of soil parameters on the representation of ecological groups within parcels.

DCA and CCA were performed using CANOCO 4.5 (ter Braak \& Smilauer 2002). MRPP was performed using 'Vegan' R-package (Oksanen et al. 2008). MANOVA was conducted unsing the 'Stats' R-package. Canonical discriminant analysis was performed using 'Candisc' R-package (Friendly 2007) ANOVAs were conducted with MINITAB 15 (Minitab Inc. 2007). Nomenclature followed Lambinon et al. (2004).

\section{Results}

\section{Soil analysis}

Reference grassland soil parameter values are provided in Table 2. Reference grassland pH was, on average, slightly acidic (Table 2), but a high standard deviation reflected large variation for this parameter, with values ranging from 4.5 to 8.5. Pearson correlations revealed that N, $P$, $\mathrm{K}, \mathrm{C}$ and $\mathrm{pH}$ transformed values exhibited inter-correlations (Table 2). Fe and $\mathrm{C}: \mathrm{N}$ were independent from each other soil parameters. The first axis of the canonical discriminant 
analysis explained $79,5 \%$ of soils parameters variation. It was mainly linked to mineralization indicators ( $\mathrm{pH}, \mathrm{Fe}, \mathrm{C}: \mathrm{N}$ ) (Fig.1). It discriminated Pre-restoration forests and 2-4 years restorations with positive coordinates, corresponding to lower $\mathrm{pH}$, higher $\mathrm{C}: \mathrm{N}$, higher Fe content, from 10-15 years restorations and reference grasslands with negative coordinates.

Table 2: Mean values and standard deviation of soil parameters in reference grasslands and Pearson correlations between transformed soil parameters. Correlation p-levels are given when significant: ${ }^{\star \star \star}: p<0.001 ;{ }^{\star \star}: 0.001<p<0.01 ;{ }^{*}: 0.01<p<0.05$.

\begin{tabular}{|c|c|c|c|c|c|c|c|c|}
\hline & $\begin{array}{c}N \\
(\%)\end{array}$ & $\begin{array}{c}P \\
(\mathrm{mg} / 100 \mathrm{~g})\end{array}$ & $\begin{array}{c}\mathrm{K} \\
(\mathrm{ppm})\end{array}$ & $\begin{array}{c}\text { C } \\
(\%)\end{array}$ & $\begin{array}{c}\mathrm{Fe} \\
(\mathrm{ppm})\end{array}$ & $\begin{array}{l}\mathrm{C}: \mathrm{N} \\
\text { ratio }\end{array}$ & $\mathrm{pH}$ & $\begin{array}{l}\text { Soil depth } \\
\text { (cm) }\end{array}$ \\
\hline Mean & 0.575 & 0.963 & 15.97 & 7.26 & 15.15 & 12.7 & 5.7 & 8.19 \\
\hline $\mathrm{pH}$ & $0.566^{\star \star}$ & $0.615^{\star \star \star}$ & 0.166 & $0.395^{\star}$ & -0.205 & -0.279 & & n.c. \\
\hline $\mathrm{C}: \mathrm{N}$ & -0.039 & 0.039 & -0.053 & 0.344 & 0.360 & & & n.c. \\
\hline $\mathrm{Fe}$ & 0.102 & -0.167 & 0.198 & 0.272 & & & & n.c. \\
\hline $\mathrm{K}$ & $0.542^{* *}$ & 0.198 & & & & & & n.c. \\
\hline$P$ & $0.614^{\star * *}$ & & & & & & & n.c. \\
\hline
\end{tabular}




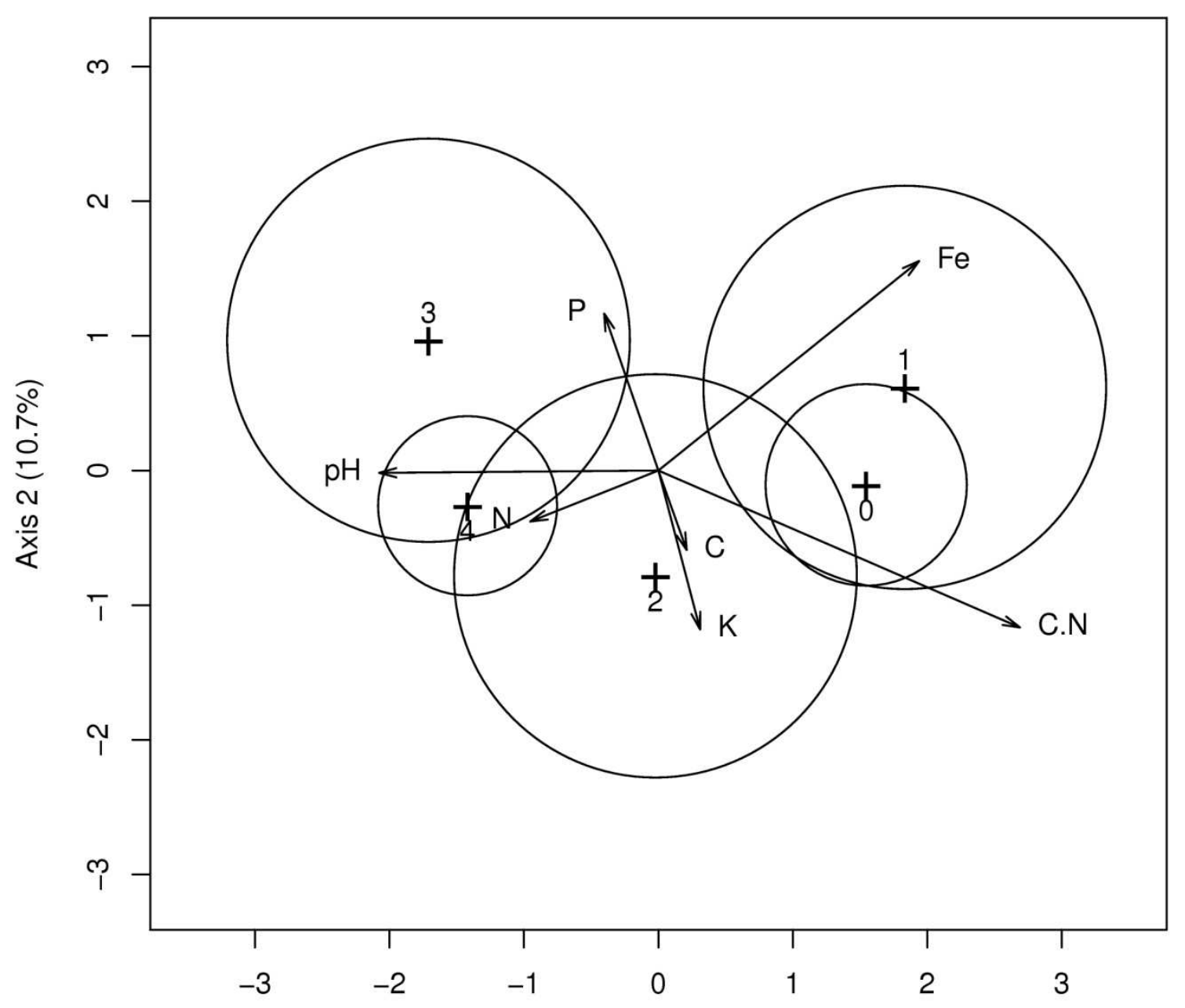

Axis $1(79.5 \%)$

Figure 1: Canonical discriminant analysis ordination plot (axes 1 and 2) of soil parameters in pre-restoration forests $(0)$, restored parcels $(1=2-4$ years: $2=5-8$ years: $3=10-15$ years) and reference grasslands (4). Mean coordinates and $95 \%$ confidence ellipses are plotted.

Comparison of transformed soil parameters revealed marginal differences among parcels types (MANOVA, Wilks' Lambda=0.154, $P=0.058$ ). The mean transformed values for $N, P, K, C$ and soil depth did not differ significantly among parcel types (Table 3). However, significant differences for $C: N$ ratio were detected. A significant positive difference was observed for $C: N$ ratio between pre-restoration forest, restored parcels 2-4 and 5-8 years old, and reference grasslands. Older restorations (10-15 years old) did not exhibit a significant difference relative to reference grasslands. Only marginal differences were found for $\mathrm{pH}$, with lower $\mathrm{pH}$ in prerestorations forests and young restorations and the highest values in older restorations. 
Althought decreasing Fe content were observed from pre-restoration forests to reference grasslands, this trend was not significant.

Table 3: Mean differences for soil parameters between reference grasslands, prerestoration forests and restored grasslands of different age classes. $(-)$ indicates a deficiency, (+) indicates a surplus. $p$-values are the result of ANOVA. Different letters indicate significant differences.

\begin{tabular}{|c|c|c|c|c|c|c|}
\hline & \multirow{2}{*}{$\begin{array}{c}\text { Pre- } \\
\text { restoration } \\
\text { forests }\end{array}$} & \multicolumn{3}{|c|}{ Restored grasslands } & \multirow{2}{*}{$\begin{array}{l}\text { Reference } \\
\text { grasslands }\end{array}$} & \multirow{2}{*}{$p$-value } \\
\hline & & $2-4$ years & $5-8$ years & $10-15$ years & & \\
\hline$N(g / 100 g)$ & -0.050 & -0.026 & +0.016 & +0.002 & 0 & 0.660 \\
\hline$P(m g / 100 g)$ & -0.012 & +0.032 & +0.032 & +0.111 & 0 & 0.941 \\
\hline $\mathrm{K}(\mathrm{ppm})$ & +0.376 & $-0,7$ & $+0,765$ & -0.63 & 0 & 0.811 \\
\hline$C(g / 100 g)$ & -0.054 & +0.463 & +0.909 & -0.04 & 0 & 0.882 \\
\hline $\mathrm{Fe}(\mathrm{ppm})$ & +3.95 & +5.76 & +2.84 & +2.77 & 0 & 0.107 \\
\hline $\mathrm{C}: \mathrm{N}$ & $+1.32^{\mathrm{a}}$ & $+1.35^{\mathrm{a}}$ & $+1.40^{\mathrm{a}}$ & $-0.093^{b}$ & $0^{\mathrm{b}}$ & 0.016 \\
\hline pH & -0.5 & -0.6 & +0.3 & +0.5 & 0 & 0.053 \\
\hline Soil depth $(\mathrm{cm})$ & +0.66 & +1.78 & -0.91 & -1.46 & 0 & 0.153 \\
\hline
\end{tabular}

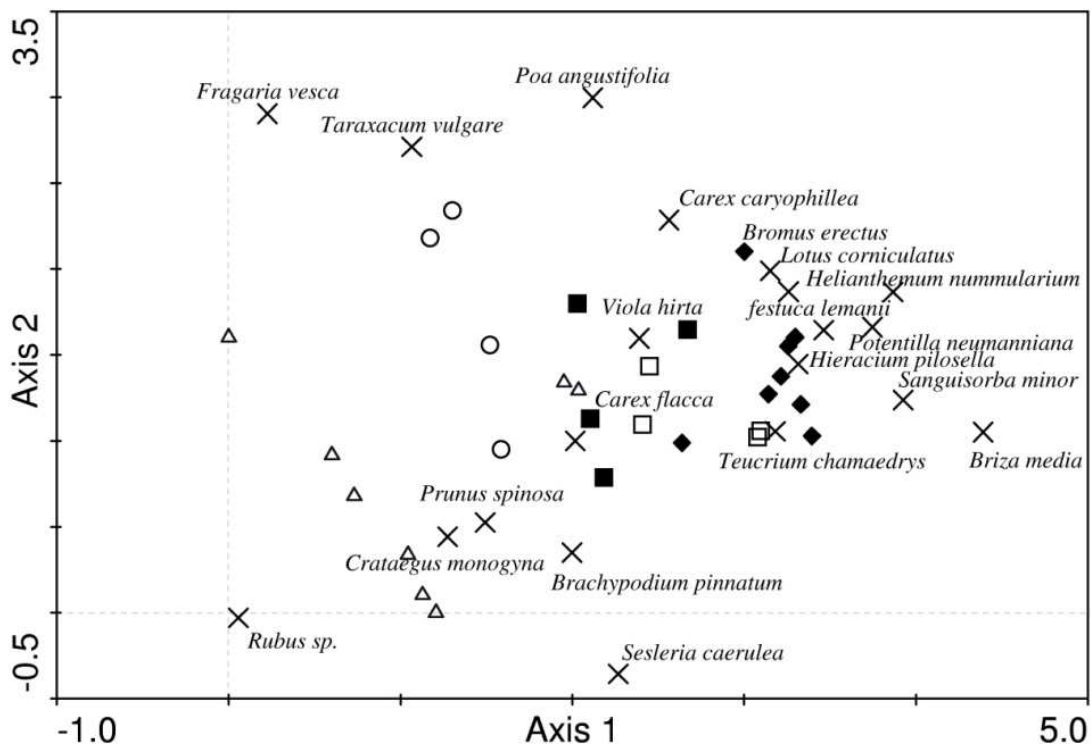

SPECIES

$X$

SAMPLES

$\triangle$ Pre-restoration forests

2-4 years

5-8 years

$\square$ 10-15 years

Reference grasslands

Figure 2: DCA ordination scatter plot (axes 1 and 2) of species composition in prerestoration forests, reference and restored calcareous grasslands of different age classes. Species with weight $>10 \%$ were plotted. 


\section{Floristic analysis}

A total of 210 species was found among our 400 vegetation samples. The first two DCA axes explained respectively $13.6 \%$ and $6,9 \%$ of the species variation among parcels (Fig. 2). The positions of parcels on axis 1 indicated the clear influence of restoration age with younger restorations (2-4 years) closer to pre-restoration forest and older restorations (10-15 years) closer to reference grasslands. MRPP showed that Bray Curtis distances estimated on species composition among age classes were significant $(A=0.139, p \times 0.001)$. Pairwise comparisons indicated significant mean Bray Curtis distance among all age class, excepted between 5-8 years and 10-15 years restorations (Table 4). Distance between age classes showed that the older a restoration was, the closer to reference grasslands it was. However, the oldest restoration and the reference grasslands were still significantly different in their species composition. Pre restoration forest samples are rather distant from every other age class. Axes 1 and 2 of the CCA respectively explained $21.1 \%$ and $13.7 \%$ of the ecological group composition variation among parcels. CCA opposed shrubs, forest and ruderal species to grassland and edge species on axis 1 (Fig. 3). This axis was correlated with high $\mathrm{N}$ content and $\mathrm{pH}$ and with low $\mathrm{C}: \mathrm{N}$ ratio and $\mathrm{Fe}$ content. Axis 2 of the CCA discriminated meadow species that were linked to the higher $K$ contents.

Table 4: Bray-Curtis mean distance between relevés of the different age classes. MRPP $p-$ levels are given when significant: ${ }^{\star \star \star}: p<0.001 ;{ }^{\star \star}: 0.001<p<0.01 ;{ }^{\star}: 0.01<p<0.05$.

\begin{tabular}{|c|c|c|c|c|c|}
\hline & \multirow{2}{*}{$\begin{array}{c}\text { Pre- } \\
\text { restoration } \\
\text { forests }\end{array}$} & \multicolumn{3}{|c|}{ Restored grasslands } \\
\hline & & & $2-4$ years & $5-8$ years & $10-15$ years \\
\hline \multirow{3}{*}{$\begin{array}{l}\text { Restored } \\
\text { grasslands }\end{array}$} & $2-4$ years & $0.70^{*}$ & & & \\
\hline & $5-8$ years & $0.71^{* *}$ & $0.62^{* *}$ & & \\
\hline & $10-15$ years & $0.73^{\star *}$ & $0.66^{*}$ & 0.51 & \\
\hline \multicolumn{2}{|c|}{ Control grasslands } & $0.81^{* * *}$ & $0.74^{* *}$ & $0.59^{*}$ & $0.52^{*}$ \\
\hline
\end{tabular}




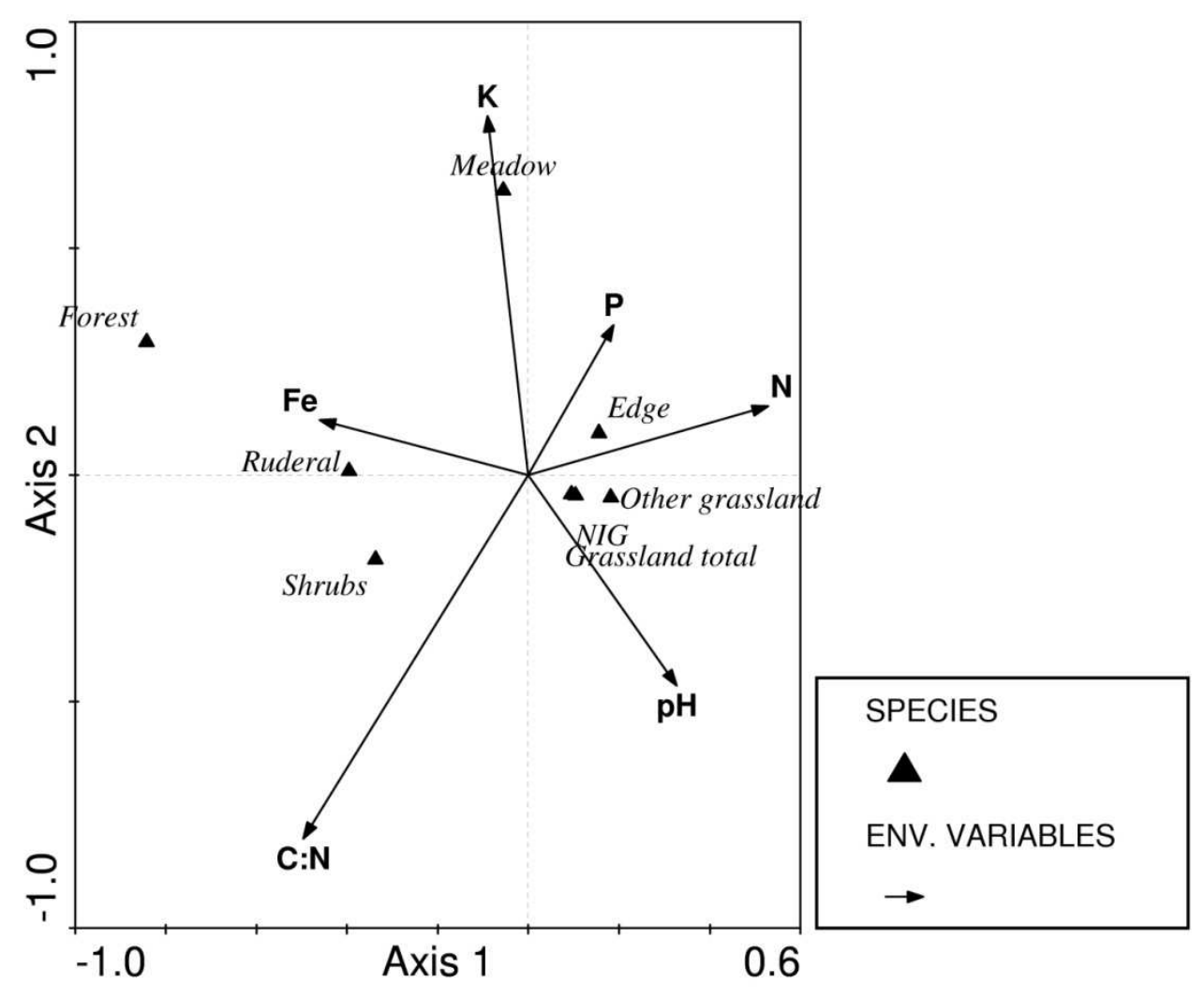

Figure 3: CCA ordination scatter plot (axes 1 and 2) of species ecological groups along soil parameters gradients.

ANOVA showed significant differences for vegetation parameters among age classes, except for the mean cover of meadow species (Table 5). Post hoc comparisons indicated that pre-restoration forests displayed lower species richness than all other parcel types. Species richness tended to increase with increasing age of restored parcels. The highest mean species richness was observed in reference grasslands but was not significantly different from 10-15 years and 5-8 years old restoration. Evenness was significantly higher in reference grasslands than in all other parcel types; while no significant difference was observed among prerestoration forests and restored parcels. The mean cover of grassland species increased with the age of restored parcels and was not significantly different between 10-15 years old restoration and reference grasslands (Table 5). However, this was mainly due to the overdevelopment of NIG as significant differences was found between reference grasslands and restored parcels for the mean cover of other grassland. NIG cover was the lowest in the forests and in 2-4 years old restored parcels. Older restoration parcels had the highest mean cover of NIG, but the difference with reference grasslands was not significant. Bare ground displayed an inverse pattern, with a minimum cover observed in oldest restorations. In oldest restorations, grassland species tended to replace ruderal species, better represented in recent restoration parcels. Pre-restoration forests were mainly characterized by a relatively high shrub cover. 
Shrub cover tended to lower with increasing restoration age, 10-15 years old restored parcels being not significantly different from reference grasslands.

Table 5: Comparisons of vegetation parameters mean values between reference grasslands, pre-restoration forests and restored grasslands of different age classes. $p$-values are the result of ANOVA. Different letters indicate significant differences.

\begin{tabular}{lcccccc}
\hline & $\begin{array}{c}\text { Pre- } \\
\text { restoration } \\
\text { forests }\end{array}$ & \multicolumn{2}{c}{ Restored grasslands } & Reference & p-value \\
& $6.3^{\mathrm{a}}$ & $15.0^{\mathrm{b}}$ & $16.8^{\mathrm{bc}}$ & $18.9^{\mathrm{bc}}$ & $20.3^{\mathrm{c}}$ & $<0.001$ \\
Species richness & $0.57^{\mathrm{a}}$ & $0.60^{\mathrm{a}}$ & $0.58^{\mathrm{a}}$ & $0.58^{\mathrm{a}}$ & $0.70^{\mathrm{b}}$ & 0.021 \\
Evenness & $24.6^{\mathrm{a}}$ & $37.8^{\mathrm{ab}}$ & $62.0^{\mathrm{bc}}$ & $72.9^{\mathrm{c}}$ & $73.6^{\mathrm{c}}$ & $<0.001$ \\
Grassland species cover & $20.0^{\mathrm{a}}$ & $16.0^{\mathrm{a}}$ & $41.7^{\mathrm{b}}$ & $39.7^{\mathrm{b}}$ & $28.7^{\mathrm{ab}}$ & 0.046 \\
NIG cover & $4.6^{\mathrm{a}}$ & $21.8^{\mathrm{b}}$ & $20.3^{\mathrm{b}}$ & $33.2^{\mathrm{c}}$ & $45.0^{\mathrm{d}}$ & $<0.001$ \\
Other grassland species cover & $0.9^{\mathrm{a}}$ & $5.0^{\mathrm{b}}$ & $4.3^{\mathrm{b}}$ & $4.1^{\mathrm{b}}$ & $6.6^{\mathrm{b}}$ & 0.008 \\
Edge species cover & $3.8^{\mathrm{a}}$ & $22.1^{\mathrm{b}}$ & $6.5^{\mathrm{ab}}$ & $1.2^{\mathrm{a}}$ & $1.2^{\mathrm{a}}$ & 0.001 \\
Ruderal species cover & $0.4^{\mathrm{b}}$ & $0.8^{\mathrm{b}}$ & $0.1^{\mathrm{a}}$ & $0.1^{\mathrm{a}}$ & $0.0^{\mathrm{a}}$ & 0.001 \\
Forest species cover & 2.2 & 1.6 & 1.9 & 2.3 & 54.7 & 0.547 \\
Meadow species cover & $22.0^{\mathrm{c}}$ & $12.4^{\mathrm{bc}}$ & $8.7^{\mathrm{bc}}$ & $5.2^{\mathrm{ab}}$ & $2.3^{\mathrm{a}}$ & 0.005 \\
Shrubs cover & $51.8^{\mathrm{c}}$ & $15.9^{\mathrm{b}}$ & $2.8^{\mathrm{a}}$ & $2.4^{\mathrm{a}}$ & $7.0^{\mathrm{ab}}$ & $<0.001$ \\
Bare ground cover & & & & &
\end{tabular}

Based on the INDVAL analysis, ten species were significant $(P<0.05)$ indicators of prerestoration forests, consisted mainly in shrubs (60\%). Thirty-eight species were significant indicators of the 2-4 years class, with $45 \%$ ruderal taxa. Ten species were significant indicators of the 5-8 years class. Ruderal species were well represented (33\%), but grassland species were also present $(27 \%)$. Fourteen and 41 species were significant ( $\left.P_{<} 0.05\right)$ indicators of the 10-15 years and reference grasslands, respectively. In both groups, grassland species were prominent (71 and $76 \%$, respectively). Further information concerning indicator species identity can be found in Appendix A. Nineteen species, mainly characteristic of calcareous grasslands, were present in reference grasslands but not in restored parcels (Anthericum liliago, Carex humilis, Cuscuta epithymum, Globularia bisnagarica, Himanthoglossum hircinum, Koeleria macrantha, Lathyrus pratensis, Melampyrum pratense, Myosotis ramosissimus, Ophrys apifera, Plantago media, Prunella laciniata, Pulsatilla vulgaris, Ranunculus bulbosus, Sorbus torminalis, Thlaspi perfoliatum, Trifolium montanum, Valerianella dentata, Veronica prostrata). Only few grassland species were found in pre-restoration forests.

\section{Discussion}

\section{How does soil of restored sites compare to reference grasslands and pre-restoration sites?}

In this study we used fertility and mineralization indicators for comparing soil characteristics among pre-restoration situations, restored ecosystems and reference grasslands. Globally our results pointed to low differences between pre-restoration and reference ecosystems, which is encouraging for calcareous grasslands restoration from 
afforested sites. However, differences in mineralization indicators were more pronounced than differences in fertility indicators.

Soil fertility level is a major factor for successful restoration, as typical calcareous grasslands are characterized by low nutrient levels (Critchley et al. 2002b; Grime 1979). Soil nutrients contents observed in reference grasslands in the present study were congruent with the literature (Critchley et al. 2002a; Janssens et al. 1998; Wells \& Cox 1993). Our results pointed out low trophic conditions for all reference sites, with low concentrations of total nitrogen and available phosphorus concentrations. Neither pre-restoration forest, i.e, parcels afforested < 100 years ago, nor restored grasslands exhibited significantly higher nutrient levels compared to adjacent reference grasslands. Our results contrast with the patterns reported about restoration of formerly arable lands (Walker et al. 2004), and are encouraging for calcareous grasslands restoration from afforested sites. However, some authors stressed the fact that grassland afforestation increased nutrient availability rather than nutrient content (Chen et al. 2008; Farley \& Kelly 2004). Further investigations are thus needed to study the different nutrient forms in restored and reference grassland soils. Also, some more synthetic indicators such as standing crop may be used as a complement to this study in order to confirm the equivalent nutrient status between restored and reference grasslands.

Multivariate analysis of soil characteristics pointed to a general pattern of differentiation between pre-restoration forests/young restorations and old restoration/reference grasslands, mainly due to mineralization indicators. However, only $C: N$ ratio showed significant difference among the parcel types and discriminated reference grasslands and old restorations from other parcel types. The lack of significant differences between old restorations and reference parcels suggests that mineralization status of restored grasslands can be restored rapidly despite initial differences. In our study, $\mathrm{pH}$ of calcareous grassland was slightly acidic $(\mathrm{pH}=5.7)$. This was due to the fact that only the upper soil layer could be analysed due to soil thinness. In this layer, intense root activity and the organic matter decomposition tends to acidify the soil solution (Mengel \& Kirkby 1987). pH tended to be lower in pre-restoration forests and young restorations as compared to reference grasslands. The lower $\mathrm{pH}$ and higher $\mathrm{C}: \mathrm{N}$ ratio in pre-restoration forests and recently restored parcels as compared to reference grasslands, may be due to a lower mineralization rate in forests, leading to a $\mathrm{pH}$ decrease.

\section{Do restoration actions lead to the reestablishment of native calcareous grassland plant communities?}

Species richness has been widely used as a biological indicator of restoration efficiency in calcareous grasslands. We observed increasing species richness with increasing restoration age, which was congruent with similar studies addressing calcareous grassland restoration (Dzwonko \& Loster 1998; Lindborg \& Eriksson 2004; Zobel et al. 1996). However, species richness cannot be used as a unique measure of successful restoration. Restoration can only be considered a 
success when referenced against target ecosystems, and sites are effectively colonized by species characteristic of those ecosystems, that establish communities with similar structure. Based on indicators of composition and structure of plant communities, our results indicated a rapid evolution of restored grasslands communities towards reference grasslands characteristics, but still with significant differences.

Floristic similarity between reference and restored grasslands increased with the age of restoration. Observed plant species succession was similar to von Blanckenhagen and Poschlod (2005) description. Firstly, ruderal species developed, and then grassland species increased without however reaching cover exhibited in reference grasslands. Contrary to Dzwonko and Loster (Dzwonko \& Loster 2007), who showed high shrub cover in ca. 10 years restored sites, we observed decreasing values of shrub cover in old restorations. This could be explained by the fact that, in our sites, shrubs were regularly mechanically cut in addition to grazing. The proportion of calcareous grassland species increased with the age of the restored patch. It suggests that a large proportion of native calcareous grassland species were able to colonize restored sites within a period of 15 years, which is encouraging for future restoration actions. However, we cannot exclude the possibility that this rapid restoration success was partly due to initial conditions of the oldest restored patches. Parcels restored first may have been less degraded at the onset of the restoration efforts. Therefore, some native grassland species may have been established prior to restoration, surviving in small calcareous grassland refugia. It has been shown by Schrautzer et al. (2009) that vegetation prior to restoration could influence restoration success. Nevertheless, our relevés revealed rather few grassland species in prerestoration forest stands. Moreover most of them were found only in the site "Les Pairées", that was one of the oldest to be restored.

Despite a general tendency towards plant communities restoration, we noted two important differences between restored and references grasslands. First, we observed a lower evenness in old restored sites. This was likely due to the dominance of native invasive grasses (NIG, indicator of plant community structure) in these areas. Second, nineteen species present in reference grasslands did not recolonize restored sites (indicator of plant composition). A similar situation was described in Central Europe grasslands (Kiefer \& Poschlod 1996). Fifteen of them are typical grassland species, which represent $24 \%$ of the grassland species found in our study. Among the missing species, ten are listed in the regional Red Data Book (Saintenoy-Simon et al. 2006): Anthericum liliago, Carex humilis, Cuscuta epithymum, Globularia bisnagarica, Himanthoglossum hircinum, Ophrys apifera, Pulsatilla vulgaris, Trifolium montanum, Veronica prostrata and Valerianella dentata. Except the last, all are typical calcareous grassland species. Furthermore, INDVAL analysis revealed that many other species remained better representated in reference grassland (Appendix 1), especially some species described as typical of ancient grasslands (Karlík \& Poschlod 2009). 
In restoration from arable fields, abiotic conditions were identified as a major constraint for plant communities restoration (Walker et al. 2004). In our study, differences in soil conditions were only revealed in pre-restoration forests and young restorations compared to reference grasslands. In older restorations, soil parameters were similar to these of reference grasslands. Therefore, soil parameters considered in this study were likely not the cause for the difference observed in species composition between old restorations and reference grasslands.

Plant community structure in oldest restored grasslands may be a constraint for the establishment of some typical grasslands species. High cover of graminoid species, such as Brachypodium pinnatum, and low bare ground availability observed on restored sites, particularly old sites, could lower availability of microsites for germination and seedling emergence of most sensitive grassland species (Kotorova \& Leps 1999; Zobel et al. 2000). Higher cover of graminoid species in restored sites may also modify competition regimes as compared to reference grasslands. It is generally admitted that graminoid species control in restored calcareous grasslands requires higher grazing pressure than in ancient grasslands (Delescaille 2000; Dutoit \& Alard 1996; Verbeke \& Lejeune 1996). The increased native invasive grass cover observed in restored patches can be due to insufficient grazing pressure. A possible explanation for such low grazing pressure is that most grazed sites include both restored and ancient grasslands, forming a unique operational grazing unit. Therefore managers often choose to under-graze the restored parcels rather than over-graze the ancient non-degraded grasslands. Additional control of native invasive grasses following restoration may be necessary to promote native calcareous grassland species recolonization. Management measures may include summer mowing of restored parcels in addition to grazing (Bobbink \& Willems 1991; Burger 1984; Green 1980).

Dispersal limitation is an alternative, non-exclusive, hypothesis we did not test in the present study to explain that a set of typical species did not recolonize restored grasslands, even after 15 years. Habitat colonization by plant species may result from both spatial and temporal (seed bank) propagule dispersal. Temporal dispersal is limited in calcareous grasslands as most target species present a transient seed bank (Bisteau \& Mahy 2005b; Kalamees \& Zobel 1997). Moreover, most calcareous grassland species are characterized by low spatial autonomous dispersal capacities (Stampfli \& Zeiter 1999). Nevertheless, restored parcels in our study were adjacent to reference grasslands, and most target species occurred within a few meters from restored site. In addition, migrating sheep flocks were used to graze restored sites among calcareous grassland patches in the study regions. Sheep are effective dispersal agents as they can bring large amounts of seeds in their fleece and dung (Couvreur et al. 2004; Fischer et al. 1996: Hellström et al. 2003). Reintroduction of sheep grazing after clear-cutting is of chief importance for the reclamation of the calcareous grassland species pool (Poschlod et al. 1998). Conditions were therefore optimal for dispersal of grassland species into restored patches. Further research should examine if non-recolonizing species and effectively recolonizing species differ in their dispersal traits. 


\section{Conclusions and implication for restoration}

Assessment of success of calcareous grassland restoration from forest stands, with soil and plant community indicators, point to a rather rapid success. Several indicators revealed that vascular plant communities tended to restore rather rapidly. However, differences still persist between 10-15 years reference grasslands and oldest restored areas. The latter had a lower evenness and were not colonized by a set of typical grassland species. This differences in plant composition persisted despite very similar soil conditions between pre-restoration forests and reference grasslands and full restoration of soil conditions in oldest restored grasslands. Higher native invasive grasses cover and lower bare ground availability in old restored parcels may be factors limiting the establishment of typical grassland species.

To ensure full success of restoration, management strategies, such as additional mowing, should aim at limiting native invasive grasses development and insure sufficient (similar to reference grasslands) bare ground availability in restored areas. Also, directed sowing of target species may help to counteract species difficulties at colonizing restored areas.

\section{Acknowledgements}

We would like to thank the Forests Sections of Rochefort, Viroinval and Wellin (head of section L. Picard (transient), J.P. Scohy and J. Gillissen respectively), the "Lesse and Lomme" and the "Haute-Meuse" LIFE-Nature projects (B. André and G. Graux) and the Marie-Victorin centre (director L. Woué). This study was supported by the FRS-FNRS (contract FRFC 2.4556.05). 


\section{References}

Adriaens D., Honnay O., Hermy M. (2006). No evidence of a plant extinction debt in highly fragmented calcareous grasslands in Belgium. Biological Conservation 133: 212-224.

Al-Mufti M.M., Sydes C.L., Furness S.B., Grime J.P., Band S.R. (1977). A quantitative analysis of shoot phenology and dominance in herbaceous vegetation. Journal of Ecology 65: 759791.

André B., Vandendorpel A. (2004). Le projet LIFE Nature de restauration et de gestion des milieux calcaires en Lesse et Lomme (PROJET LIFE2000NATURE/B/7168) : une tradition pastorale séculaire en dernier recours. Parcs \& Réserves 59: 22-37.

Bakker J.P., Berendse F. (1999). Constraints in the restoration of ecological diversity in grassland and heathland communities. Trends in Ecology \& Evolution 14: 63-68.

Bisteau E., Mahy G. (2005a). A landscape approach for the study of calcareous grassland plant communities. Biotechnologie, Agronomie, Société, Environnement 9: 93-99.

Bisteau E., Mahy G. (2005b). Vegetation and seed bank in a calcareous grassland restored from a Pinus forest. Applied Vegetation Science 8: 167-174.

Bobbink R., Willems J.H. (1991). Impact of different cutting regimes on the performance of Brachypodium pinnatum in Dutch chalk grassland. Biological Conservation 56: 1-21.

Bobbink R., Hornung M., Roelefs J.G.M. (1998). The effects of air-borne nitrogen pollutants on species diversity in natural and semi-natural European vegetation. Journal of Ecology 86: 717-738.

Bonneau M., Souchier B. (1979). Constituants et propriétés du sol in Duchaufour P., Souchier B., eds. Pédologie. Paris, France: Masson.

Bremner J.M., Mulvaney C.S. (1982). Nitrogen total. Pages 595-624 in Page A.L., ed. Methods of soil analysis, vol. 9, Part 2 : Chemical and microbiological properties. Madison, WI, USA.: Am. Soc. Agron.

Burger R. (1984). Successional limestone grassland communities of the Kaiserstuhl, with regard to their conservation management. Coll. Phytosoc. 11: 405-420.

Butaye J., Honnay O., Adriaens D., Delescaille L.M., Hermy M. (2005). Phytosociology and phytogeography of the calcareous grasslands on Devonian limestone in Southwest Belgium. Belgian Journal of Botany 138: 24-38.

Chen C.R., Condron L.M., Xu Z.H. (2008). Impacts of grassland afforestation with coniferous trees on soil phosphorus dynamics and associated microbial processes: $A$ review. Forest Ecology and Management 255: 396-409.

Couvreur M., Christiaen B., Verheyen K., Hermy M. (2004). Large herbivores as mobile links between isolated nature reserves through adhesive seed dispersal. Applied Vegetation Science 7: 229-236.

Cristofoli S., Piqueray J., Dufrêne M., Bizoux J.P., Mahy G. (2009). Colonization credit in restored wet heathlands. Restoration Ecology. In press.

Critchley C.N.R., Chambers B.J., Fowbert J.A., Sanderson R.A., Bhogal A., Rose S.C. (2002a). Association between lowland grassland plant communities and soil properties. Biological Conservation 105: 199-215.

Critchley C.N.R., Chambers B.J., Fowbert J.A., Bhogal A., Rose S.C., Sanderson R.A. (2002b). Plant species richness, functional type and soil properties of grasslands and allied vegetation in English environmentally sensitive areas. Grass and forage science 57: 8292.

Delescaille L.M. (2000). La gestion conservatoire de la pelouse calcicole du Chamousia à Viervessur-Viroin (Province de Namur, Belgique) : comparaison de la fauche hivernale et du 
pâturage ovin en saison de végétation sur la structure et la composition du tapis végétal. Parcs \& Réserves 55: 2-9.

Dufrêne M., Legendre P. (1997). Species assemblages and indicator species: the need for a flexible asymetrical approach. Ecological monographs 67: 345-366.

Dutoit T., Alard D. (1996). Restauration d'un système de parcours sur les pelouses calcicoles de la vallée de la Seine (Haute-Normandie, France). Pages 47-54. Actes du colloque international : "La gestion des pelouses calcicoles". Vierves-sur-Viroin: Cercles des naturalistes de Belgique.

Dzwonko Z., Loster S. (1998). Dynamics of species richness and composition in a limestone grassland restored after tree cutting. Journal of vegetation science 9: 387-394.

Dzwonko Z., Loster S. (2007). A functional analysis of vegetation dynamics in abandoned and restored limestone grasslands. Journal of Vegetation Science 18: 203-212.

Fagan K.C., Pywell R.F., Bullock J.M., Marrs R.H. (2008). Do restored calcareous grasslands on former arable fields resemble ancient targets? The effect of time, methods and environment on outcomes. Journal of Applied Ecology 45: 1293-1303.

Farley K.A., Kelly E.F. (2004). Effects of afforestation of a páramo grassland on soil nutrient status. Forest Ecology and Management 195: 281-290.

Fischer S.F., Poschlod P., Beinlich B. (1996). Experimental studies on the dispersal of plants and animals on sheep in calcareous grasslands. Journal of Applied Ecology 33: 1206-1222.

Friendly M. (2007). HE plots for Multivariate General Linear Models. Journal of Computational and Graphical Statistics 16: 421-444.

Graux G. (2004). Le projet LIFE "restauration et gestion durable des pelouses sèches en Haute Meuse". Parcs \& Réserves 59: 38-48.

Green B.H. (1972). The relevance of seral eutrophication and plant competition to the management of successional communities. Biological Conservation 4: 378-384.

Green B.H. (1980). Management of extensive amenity grasslands by mowing. Pages 155-161 in Rorison I.H., Hunt R., eds. Amenity grassland: an ecological perspective. Wiley, Chichester.

Grime J.P. (1979). Plant strategies and vegetation processes. Chichester: Wiley. $222 \mathrm{p}$.

Hellström K., Huhta A.P., Rautio P., Tuomi J., Oksanen J., Laine K. (2003). Use of sheep grazing in the restoration of semi-natural meadows in northern Finland. Applied vegetation science 6: 45-52.

Holl K.D., Cairns J. (2002). Monitoring and appraisal. Pages 409-432 in Perrow M.R., Davy A.J., eds. Handbook of ecological restoration. Principles of restoration. Cambridge: Cambridge University Press.

Hurst A., John E. (1999). The biotic and abiotic changes associated with Brachypodium pinnatum dominance in chalk grassland in south-east England. Biological Conservation 88: 75-84.

Hutchings M.J., Stewart A.J.A. (2002). Calcareous grasslands. Pages 419-442 in Perrow M.R., Davy A.J., eds. Handbook of ecological restoration. Restoration in practice. Cambridge: Cambridge University Press.

Jacquemyn H., Brys R., Hermy M. (2003). Short-term effects of different management regimes on the response of calcareous grassland vegetation to increased nitrogen. Biological Conservation 111: 137-147.

Janssens F., Peeters A., Tallowin R.J.B., Bakker J.P., Bekker R.M., Fillat F., Oomes M.J.M. (1998). Relationship between soil chemical factors and grassland diversity. Plant and Soil 202: 69-78.

Jongman R.H.G., Pungetti G., eds. (2004). Ecological networks and greenways: concept, design, implementation Cambridge, UK: Cambridge University Press. 345 p.

Jordan W.R.I., Gilpin M.E., Aber J.D., eds. (1987). Restoration Ecology. A synthetic approach to ecological research Cambridge, UK: Cambridge University Press. p. 
Kalamees R., Zobel M. (1997). The seed bank in an Estonian calcareous grassland: comparison of different successional stages. Folia Geobotanica et Phytotaxonomica 32: 1-14.

Karlík P., Poschlod P. (2009). History or abiotic filter: which is more important in determining the species composition of calcareous grasslands. Preslia 81: 321-340.

Kiefer S., Poschlod P. (1996). Restoration of fallow or afforested calcareous grassland by clearcutting. Pages 209-218 in Settele J., Margules C.R., Poschlod P., Henle K., eds. Species survival in fragmented landscapes. The Netherlands: Kluwer academics publishers.

Kiehl K., Thormann A., Pfadenhauer J. (2006). Evaluation of initial restoration measures during the restoration of calcareous grasslands on former arable fields. Restoration Ecology 14: 148-156.

Kotorova I., Leps J. (1999). Comparative ecology of seedling recruitment in an oligotrophic wet meadow. Journal of Vegetation Science 10: 175-186.

Lambinon J., Delvosalle L., Duvigneaud J. (2004). Nouvelle flore de Belgique, du Grand-Duché de Luxembourg, du Nord de la France et des régions voisines. Meise: Jardin botanique national de Belgique. $p$.

Lindborg R., Eriksson O. (2004). Effects of restoration on plant species richness and composition in Scandinavian semi-natural grasslands. Restoration Ecology 12: 318-326.

Mengel K., Kirkby E.A. (1987). Principles of plant nutrition. Bern, Switzerland: International Potash Institute. $p$.

Mortimer S.R., Hollier J.A., Brown V.K. (1998). Interactions between plant and insect diversity in the restoration of lowland calcareous grasslands in southern Britain. Applied Vegetation Science 1: 101-114.

Oksanen J., Kindt R., Legendre P., O'Hara B., Simpson G.L., Solymos P., Stevens M.H.H., Wagner H. 2008. Community ecology package Version 1.15-1. (23/01/2009 http://vegan.r-forge.rproject.org/)

Olsen S.R., Sommers L.E. (1982). Phosphorus. Pages 403-430 in Page A.L., ed. Methods of soil analysis, vol. 9, Part 2 : Chemical and microbiological properties. Madison, WI, USA.: Am. Soc. Agron.

Ouro G., Perez-Batallon P., Merino A. (2001). Effects of sylvicultural practices on nutrient status in a Pinus radiata plantation: nutrient export by tree removal and nutrient dynamics in decomposing logging residues. Annals of Forest Science 58: 411-422.

Pärtel M., Kalamees R., Zobel M., Rosén E. (1998). Restoration of species-rich limestone grassland communities from overgrown land: the importance of propagule availability. Ecological Engineering 10: 275-286.

Perrow M.R., Davy A.J. (2002). Handbook of ecological restoration. Cambridge: Cambridge University Press. p.

Piqueray J., Mahy G. (2009). Revue bibliographique sur la restauration des pelouses calcicoles en Europe : contraintes rencontrées et solutions proposées. Biotechnologie, Agronomie, Société, Environnement. In press.

Piqueray J., Bisteau E., Bottin G., Mahy G. (2007). Plant communities and species richness of the calcareous grasslands in southeast Belgium. Belgian Journal of Botany 140: 157-173.

Poschlod P., WallisDeVries M.F. (2002). The historical and socioeconomic perspective of calcareous grasslands: lessons from the distant and recent past. Biological Conservation 104: 361-376.

Poschlod P., Kiefer S., Tränkle U., Fischer S., Bonn S. (1998). Plant species richness in calcareous grasslands as affected by dispersability in space and time. Applied Vegetation Science 1: 75-90.

Prendergast J.R., Quinn R.M., Lawton J.H., Eversham B.C., Gibbons D.W. (1993). Rare species, the coincidence of diversity hotspots and conservation strategies. Nature 365: 335-337. 
Ross D.J., Tate K.R., Scott N.A., Feltham C.W. (1999). Land-use change: effects on soil carbon, nitrogen and phosphorus pools and fluxes in three adjacent ecosystems. Soil biology and biochemistry 31: 803-813.

Ruiz-Jaen M.C., Aide T.M. (2005). Restoration success: How is it being measured. Restoration Ecology 13: 569-577.

Saintenoy-Simon J., Barbier Y., Delescaille L.M., Dufrêne M., Gathoye J.L., Verté P. 2006. Première liste des espèces rares, menacées et protégées de la Région Wallonne (Ptéridophytes et Spermatophytes). (29 September 2008 http://mrw.wallonie.be/dgrne/sibw/especes/ecologie/plantes/listerouge/)

Samu F., Csontos P., Szinetár C. (2008). From multi-criteria approach to simple protocol: Assessing habitat patches for conservation value using species rarity. Biological Conservation 141: 1310-1320.

Schrautzer J., Jansen D., Breuer M., Nelle O. (2009). Succession and management of calcareous dry grasslands in the Northern Franconian Jura, Germany. Tuexenia 29: 339-351.

Society for Ecological Restoration International Science \& Policy Working Group. 2004. The SER International Primer on Ecological Restoration. (6 March 2008 http://www.ser.org)

Stampfli A., Zeiter M. (1999). Plant species decline due to abandonment of meadows cannot easily be reverse by mowing: a case study from the southern Alps. Journal of vegetation science 10: 151-164.

ter Braak C.F.J., Smilauer P. (2002). CANOCO reference manual and CanoDraw for Windows user's Guide: software for canonical community ordination (version 4.5). Ithoca, NY, USA: Microcomputer Power. 500 p.

Thuille A., Schulze E.D. (2006). Carbon dymanics in successional and afforested spruce stands in Thuringia and the Alps. Global Change Biology 12: 325-342.

Vandermotten C., Decroly J.M. (1995). Géographie. Pages 463 in Joris F., ed. Wallonie. Atouts et références d'une Région. Namur: Gouvernement wallon.

Verbeke W., Lejeune M. (1996). Pâturage ou fauchage, la meilleure gestion pour la flore des pelouses calcicoles? Pages 55-59. Actes du colloque: "La gestion des pelouses calcicoles". Vierves-sur-Viroin: Cercles des naturalistes de Belgique.

von Blanckenhagen B., Poschlod P. (2005). Restoration of calcareous grasslands: the role of the soil seed bank and seed dispersal for recolonisation processes. Biotechnologie, Agronomie, Société, Environnement 9: 143-149.

Walker K.J., Stevens P.A., Stevens D.P., Mountford J.O., Manchester S.J., Pywell R.F. (2004). The restoration and re-creation of species-rich lowland grassland on land formerly managed for intensive agriculture in the UK. Biological Conservation 119: 1-18.

WallisDeVries M.F., Poschlod P., Willems J.H. (2002). Challenges for the conservation of calcareous grasslands in northwestern Europe: integrating the requirements of flora and fauna. Biological Conservation 104: 265-273.

Wells T.C.E., Cox R. (1993). The long-term effects of cutting on the yield, floristic composition and soil nutrient status of chalk grassland: English Nature. $82 \mathrm{p}$.

Willems J.H. (2001). Problems, approaches, and results in restoration of Dutch calcareous grassland during the last 30 years. Restoration Ecology 9: 147-154.

Willems J.H., Peet R.K., Bik L.P.M. (1993). Changes in chalk-grassland structure and species richness resulting from selective nutrient additions. Journal of Vegetation Science 4: 203-212.

Zobel M., Suurkask M., Rosén E., Pärtel M. (1996). The dynamics of species richness in an experimentally restored calcareous grassland. Journal of vegetation science 7: 203-210.

Zobel M., Otsus M., Liira J., Moora M., Möls T. (2000). Is small-scale species richness limited by seed availability or microsite availability? Ecology 81: 3274-3282. 


\section{Appendix}

Appendix A: Occurrence of species in the five age classes. First value is the number of relevés where it occurred (total number of relevés is 80 in each class). Second value is the mean abundance [\%] in relevés where it occurred. Only significant indicators were listed. Age class for which they were indicator is in bold and underlined.

\begin{tabular}{|c|c|c|c|c|c|c|}
\hline \multirow[b]{2}{*}{ Species } & \multirow{2}{*}{$\begin{array}{l}\text { Pre- } \\
\text { restoration } \\
\text { forests }\end{array}$} & \multicolumn{3}{|c|}{ Restored grasslands } & \multirow[b]{2}{*}{$\begin{array}{l}\text { Reference } \\
\text { grasslands }\end{array}$} & \multirow[b]{2}{*}{$\begin{array}{c}\text { Ecological } \\
\text { group }\end{array}$} \\
\hline & & $\begin{array}{c}2-4 \\
\text { years }\end{array}$ & $\begin{array}{c}5-8 \\
\text { years }\end{array}$ & $\begin{array}{l}10-15 \\
\text { years }\end{array}$ & & \\
\hline Anthericum liliago & 0/- & $0 /-$ & $0 /-$ & $0 /-$ & $\underline{9 / 2.1}$ & Edge \\
\hline Anthyllis vulneraria & $0 /-$ & $2 / 1$ & $4 / 2$ & $2 / 0.5$ & $8 / 0.9$ & Grassland \\
\hline Arenaria sepyllifolia & 0/- & $\underline{9 / 1}$ & $0 /-$ & 0/- & $2 / 0.8$ & Grassland \\
\hline Avenula pubescens & $1 / 0.5$ & $\overline{1 / 1}$ & $5 / 1.2$ & $\underline{40 / 0.8}$ & $16 / 0.8$ & Meadow \\
\hline Brachypodium pinnatum & $52 / 26.8$ & $40 / 32$ & $79 / 33.4$ & $\underline{80 / 36.1}$ & $77 / 21.4$ & Grassland \\
\hline Briza media & 0/- & 0/- & $3 / 2$ & $26 / 2.1$ & $\underline{45 / 3}$ & Grassland \\
\hline Bromus erectus & $11 / 19.2$ & $0 /-$ & $22 / 31.8$ & $19 / 15$ & $30 / 24.1$ & Grassland \\
\hline Campanula rotundifolia & $1 / 0.5$ & $9 / 1$ & $27 / 0.5$ & $\underline{48 / 0.6}$ & $36 / 0.6$ & Grassland \\
\hline Carex caryophyllea & $1 / 10$ & $13 / 10.4$ & $15 / 6.1$ & $35 / 2.4$ & $\underline{44 / 2.6}$ & Grassland \\
\hline Carex flacca & $23 / 10.1$ & $58 / 15.8$ & $56 / 8.6$ & $\underline{78 / 13}$ & $57 / 7.1$ & Grassland \\
\hline Carex humilis & 0/- & 0/- & 0/- & 0/- & $\underline{10 / 12.3}$ & Edge \\
\hline Carlina vulgaris & $0 /-$ & 0/- & $1 / 1$ & $1 / 0.5$ & $\underline{4 / 0.8}$ & Grassland \\
\hline Carpinus betulus & $10 / 0.9$ & $\underline{12 / 1.7}$ & $3 / 0.7$ & 0/- & $3 / 0.7$ & Shrub \\
\hline Catapodium rigidum & 0/- & $\underline{4 / 0.6}$ & 0/- & $0 /-$ & 0/- & Grassland \\
\hline Centaurea scabiosa & $0 /-$ & $2 / 0.5$ & $6 / 0.9$ & $24 / 1.6$ & $\underline{24 / 1.9}$ & Grassland \\
\hline Centaurea jacea & $0 /-$ & $2 / 0.5$ & $4 / 1.5$ & $38 / 2.7$ & $\underline{38 / 3}$ & Meadow \\
\hline Cerastium fontanum & $0 /-$ & $\underline{6 / 1.3}$ & 0/- & $1 / 0.5$ & $0 /-$ & Meadow \\
\hline Cerastium pumilum & $0 /-$ & 0/- & $3 / 1$ & 0/- & $\underline{6 / 0.5}$ & Grassland \\
\hline Cirsium acaule & $0 /-$ & 0/- & $3 / 6.7$ & $9 / 1.3$ & $\underline{13 / 4.3}$ & Grassland \\
\hline Cirsium arvense & $0 /-$ & $\underline{19 / 1.3}$ & $1 / 1$ & 0/- & 0/- & Ruderal \\
\hline Cirsium vulgare & 0/- & $\underline{37 / 2.6}$ & $3 / 0.8$ & $0 /-$ & $0 /-$ & Ruderal \\
\hline Clematis vitalba & $\underline{13 / 13.2}$ & $16 / 1.1$ & $10 / 5.4$ & $1 / 0.5$ & $1 / 1$ & Shrub \\
\hline Convolvulus arvensis & 0/- & $1 / 0.5$ & $\underline{4 / 5.8}$ & 0/- & $0 /-$ & Ruderal \\
\hline Cornus mas & $\underline{6 / 2}$ & 0/- & 0/- & 0/- & 0/- & Shrub \\
\hline Cuscuta epithymum & $0 /-$ & 0/- & $0 /-$ & 0/- & $\underline{5 / 0.5}$ & Grassland \\
\hline Cytisus scoparius & $0 /-$ & $\underline{9 / 0.7}$ & $0 /-$ & 0/- & 0/- & Shrub \\
\hline Danthonia decumbens & $0 /-$ & $1 / 0.5$ & $0 /-$ & $3 / 0.7$ & $\underline{6 / 2.5}$ & Grassland \\
\hline Daucus carota & 0/- & $\underline{10 / 0.6}$ & 0/- & 0/- & $5 / 0.8$ & Ruderal \\
\hline Echium vulgare & 0/- & $2 / 1.5$ & $\underline{5 / 4.5}$ & 0/- & 0/- & Ruderal \\
\hline Eupatorium cannabinum & $0 /-$ & $\underline{10 / 5.3}$ & $4 / 3.1$ & 0/- & $0 /-$ & Ruderal \\
\hline Euphorbia amygdaloides & 0/- & $2 / 1.5$ & 9/0.7 & $8 / 0.6$ & 0/- & Forest \\
\hline Euphorbia cyparissias & $7 / 1.4$ & $\underline{28 / 2.7}$ & $24 / 1$ & $24 / 1.6$ & $24 / 1.4$ & Grassland \\
\hline Festuca lemanii & 0/- & $9 / 32.9$ & $13 / 5.2$ & $42 / 11.6$ & $\underline{68 / 5.2}$ & Grassland \\
\hline Festuca rubra & $\underline{12 / 11}$ & 0/- & $4 / 1.6$ & 0/- & $2 / 37.5$ & Meadow \\
\hline Fragaria vesca & $17 / 4$ & $\underline{61 / 16.7}$ & $43 / 3.9$ & $2 / 2.5$ & $10 / 1.3$ & Ruderal \\
\hline Fragaria viridis & 0/- & 0/- & 0/- & $\underline{32 / 1}$ & $16 / 7.1$ & Grassland \\
\hline Fraxinus exelsior & $\underline{10 / 2.1}$ & $3 / 1$ & $2 / 0.5$ & $0 /-$ & $1 / 1$ & Shrub \\
\hline Galium aparine & $6 / 0.7$ & $\underline{19 / 0.6}$ & $1 / 0.5$ & 0/- & $0 /-$ & Ruderal \\
\hline Galium mollugo & $4 / 0.6$ & $13 / 4.2$ & $5 / 0.7$ & 0/- & $1 / 1$ & Ruderal \\
\hline Galium pumilum & $4 / 0.5$ & $3 / 2.8$ & $43 / 0.9$ & $\underline{66 / 1.3}$ & $52 / 0.7$ & Grassland \\
\hline Galium verum & 0/- & $1 / 0.5$ & $12 / 3.5$ & $22 / 1.1$ & $\underline{24 / 3.6}$ & Edge \\
\hline
\end{tabular}




\begin{tabular}{|c|c|c|c|c|c|c|}
\hline \multirow[b]{2}{*}{ Species } & \multirow{2}{*}{$\begin{array}{l}\text { Pre- } \\
\text { restoration } \\
\text { forests }\end{array}$} & \multicolumn{3}{|c|}{ Restored grasslands } & \multirow[b]{2}{*}{$\begin{array}{l}\text { Reference } \\
\text { grasslands }\end{array}$} & \multirow[b]{2}{*}{$\begin{array}{l}\text { Ecological } \\
\text { group }\end{array}$} \\
\hline & & $\begin{array}{c}2-4 \\
\text { years }\end{array}$ & $\begin{array}{c}5-8 \\
\text { years }\end{array}$ & $\begin{array}{l}10-15 \\
\text { years }\end{array}$ & & \\
\hline Genista tinctoria & $0 /-$ & $1 / 0.5$ & $8 / 0.8$ & $\underline{18 / 2.6}$ & $13 / 2.8$ & Grassland \\
\hline Genistella sagittalis & $0 /-$ & $1 / 0.5$ & 0/- & $25 / 1.2$ & $\underline{22 / 2.3}$ & Grassland \\
\hline Geranium robertianum & $3 / 0.7$ & $\underline{5 / 1.4}$ & $0 /-$ & 0/- & 0/- & Forest \\
\hline Geum urbanum & $4 / 1.8$ & $\overline{11 / 0.8}$ & $2 / 0.5$ & $0 /-$ & $0 /-$ & Ruderal \\
\hline Hedera helix & $\underline{7 / 0.6}$ & $3 / 0.5$ & $0 /-$ & $1 / 0.5$ & 0/- & Forest \\
\hline Helianthemum nummularium & $\overline{2 / 1.3}$ & $4 / 1$ & $38 / 3.3$ & $43 / 1.7$ & $\underline{54 / 8.1}$ & Grassland \\
\hline Hieracium pilosella & 0/- & $5 / 1.2$ & $17 / 4.6$ & 0/- & $\underline{28 / 4.7}$ & Grassland \\
\hline Hippocrepis comosa & $0 /-$ & $14 / 2.2$ & $11 / 0.6$ & $1 / 5$ & $\underline{18 / 4}$ & Grassland \\
\hline Hypericum perforatum & $0 /-$ & $35 / 1.2$ & $\underline{43 / 0.7}$ & $32 / 0.5$ & $35 / 0.7$ & Ruderal \\
\hline Inula conyzae & $0 /-$ & $\underline{14 / 1.6}$ & $9 / 2$ & 0/- & $3 / 2.2$ & Edge \\
\hline Knautia arvensis & $0 /-$ & $1 / 1$ & $4 / 1.8$ & $17 / 1.3$ & $\underline{18 / 3.1}$ & Meadow \\
\hline Koeleria macrantha & $0 /-$ & 0/- & 0/- & 0/- & $\underline{24 / 1.6}$ & Grassland \\
\hline Lapsana communis & $1 / 1$ & $\underline{16 / 1.9}$ & 0/- & 0/- & 0/- & Ruderal \\
\hline Leontodon hispidus & $0 /-$ & $1 / 0.5$ & $10 / 1.8$ & $\underline{24 / 0.9}$ & $16 / 4.2$ & Grassland \\
\hline Leucanthemum vulgare & $0 /-$ & $1 / 5$ & $3 / 1.3$ & 0/- & $\underline{5 / 3.2}$ & Meadow \\
\hline Ligustrum vulgare & $4 / 2$ & $0 /-$ & $\underline{9 / 5.3}$ & $1 / 0.5$ & $1 / 0.5$ & Shrub \\
\hline Linum catharticum & $0 /-$ & $4 / 0.5$ & $31 / 0.8$ & $\underline{45 / 0.6}$ & $29 / 0.5$ & Grassland \\
\hline Lotus corniculatus & 0/- & $25 / 1.2$ & $41 / 1.4$ & $53 / 1.5$ & $\underline{60 / 1.6}$ & Grassland \\
\hline Medicago lupulina & $1 / 0.5$ & $4 / 0.8$ & $3 / 2.8$ & $3 / 0.5$ & $12 / 0.7$ & Grassland \\
\hline Mercurialis perrenis & $1 / 1$ & $\underline{4 / 7.3}$ & $0 /-$ & $0 /-$ & 0/- & Forest \\
\hline Mycelis muralis & $3 / 1$ & $\overline{8 / 0.5}$ & $4 / 0.6$ & 0/- & $0 /-$ & Forest \\
\hline Myosotis arvensis & $1 / 0.5$ & $\underline{12 / 1.4}$ & $5 / 1$ & $0 /-$ & $3 / 1.5$ & Ruderal \\
\hline Myosotis ramosissima & 0/- & 0/- & 0/- & $0 /-$ & $\underline{5 / 0.5}$ & Grassland \\
\hline Ononis repens & $0 /-$ & $0 /-$ & $1 / 0.5$ & $2 / 2$ & $\underline{5 / 1.1}$ & Grassland \\
\hline Origanum vulgare & $0 /-$ & $\underline{15 / 4.1}$ & $4 / 4.5$ & $0 /-$ & $6 / 1.7$ & Edge \\
\hline Picris hieracioides & $0 /-$ & $10 / 3.7$ & $5 / 3.2$ & $0 /-$ & 0/- & Ruderal \\
\hline Pimpinella saxifraga & $0 /-$ & $4 / 0.5$ & $\underline{45 / 0.7}$ & $39 / 0.6$ & $34 / 1$ & Grassland \\
\hline Pinus sylvestris & $0 /-$ & 0/- & $1 / 0.5$ & 0/- & $\underline{5 / 0.9}$ & Shrub \\
\hline Plantago lanceolata & $0 /-$ & $10 / 1.4$ & 0/- & $11 / 0.6$ & $\underline{28 / 2}$ & Meadow \\
\hline Plantago major & $0 /-$ & $\underline{7 / 1.4}$ & $0 /-$ & 0/- & 0/- & Meadow \\
\hline Plantago media & 0/- & 0/- & 0/- & 0/- & $\underline{9 / 1.8}$ & Grassland \\
\hline Plathantera chlorantha & $2 / 0.8$ & 0/- & $\underline{18 / 0.9}$ & $10 / 0.7$ & $4 / 1.4$ & Grassland \\
\hline Poa nemoralis & $\underline{6 / 2.6}$ & $2 / 10.3$ & 0/- & 0/- & 0/- & Forest \\
\hline Poa pratensis & $0 /-$ & $22 / 6.8$ & $\underline{31 / 3.4}$ & $24 / 3.8$ & $15 / 8.4$ & Edge \\
\hline Poa trivialis & $4 / 3.1$ & $\underline{6 / 4.4}$ & $2 / 0.5$ & 0/- & 0/- & Meadow \\
\hline Polygala comosa & 0/- & $2 / 0.5$ & $7 / 0.6$ & $\underline{16 / 0.6}$ & $6 / 0.6$ & Grassland \\
\hline Polygala vulgaris & $0 /-$ & $11 / 1.5$ & $\underline{13 / 2.1}$ & 0/- & $10 / 0.8$ & Grassland \\
\hline Potentilla neumanniana & $1 / 0.5$ & $12 / 0.9$ & $27 / 0.7$ & $33 / 0.9$ & $\underline{58 / 2.5}$ & Grassland \\
\hline Primula veris & $4 / 1.1$ & $\underline{10 / 3.6}$ & $6 / 2$ & $2 / 10.3$ & $3 / 0.7$ & Grassland \\
\hline Prunella laciniata & 0/- & 0/- & $0 /-$ & 0/- & $\underline{4 / 1.1}$ & Grassland \\
\hline Prunus avium & $\underline{3 / 0.8}$ & 0/- & 0/- & 0/- & $0 /-$ & Shrub \\
\hline Prunus spinosa & $41 / 3.5$ & $32 / 5.8$ & $43 / 4.8$ & $\underline{61 / 4.3}$ & $22 / 4.6$ & Shrub \\
\hline Pulsatilla vulgaris & 0/- & 0/- & 0/- & 0/- & $\underline{5 / 4.1}$ & Grassland \\
\hline Ranunculus bulbosus & $0 /-$ & $0 /-$ & $0 /-$ & $0 /-$ & $\underline{13 / 1.8}$ & Grassland \\
\hline
\end{tabular}


Calcareous grassland restoration from forest stands

\begin{tabular}{|c|c|c|c|c|c|c|}
\hline \multirow[b]{2}{*}{ Species } & \multirow{2}{*}{$\begin{array}{c}\text { Pre- } \\
\text { restoration } \\
\text { forests }\end{array}$} & \multicolumn{3}{|c|}{ Restored grasslands } & \multirow[b]{2}{*}{$\begin{array}{l}\text { Reference } \\
\text { grasslands }\end{array}$} & \multirow[b]{2}{*}{$\begin{array}{c}\text { Ecological } \\
\text { group }\end{array}$} \\
\hline & & $\begin{array}{c}2-4 \\
\text { years }\end{array}$ & $\begin{array}{c}5-8 \\
\text { years }\end{array}$ & $\begin{array}{l}10-15 \\
\text { years }\end{array}$ & & \\
\hline Ranunculus repens & 0/- & $\underline{6 / 0.7}$ & $0 /-$ & $0 /-$ & $1 / 0.5$ & Meadow \\
\hline Rosa arvensis & $8 / 9.2$ & $0 /-$ & $0 /-$ & $0 /-$ & 0/- & Shrub \\
\hline Rosa canina & $13 / 4.1$ & $20 / 1.5$ & $\underline{29 / 1.1}$ & $19 / 0.6$ & $7 / 0.7$ & Shrub \\
\hline Rubus idaeus & $1 / 35$ & $\underline{6 / 2.6}$ & $0 /-$ & 0/- & 0/- & Shrub \\
\hline Rubus sp. & $38 / 28.1$ & $65 / 7.3$ & $18 / 8.1$ & $8 / 0.9$ & $0 /-$ & Shrub \\
\hline Sanguisorba minor & 0/- & $12 / 0.9$ & $30 / 1.7$ & $49 / 4$ & $\underline{68 / 5.4}$ & Grassland \\
\hline Scabiosa columbaria & 0/- & 0/- & $3 / 2.7$ & $36 / 0.8$ & $36 / 2.6$ & Grassland \\
\hline Senecio jacobaea & 0/- & $\underline{7 / 2}$ & $1 / 3$ & 0/- & $2 / 0.8$ & Ruderal \\
\hline Sesleria caerulea & $9 / 10.2$ & $\overline{4 / 5.5}$ & $\underline{27 / 6.6}$ & $17 / 4.5$ & $24 / 9$ & Grassland \\
\hline Solidago virgaurea & 0/- & 0/- & $1 / 1$ & $\underline{20 / 1.7}$ & $1 / 4$ & Ruderal \\
\hline Sonchus arvensis & 0/- & $11 / 0.7$ & $\underline{19 / 0.9}$ & $4 / 0.5$ & $1 / 0.5$ & Ruderal \\
\hline Sonchus asper & 0/- & $\underline{14 / 0.5}$ & 0/- & 0/- & 0/- & Ruderal \\
\hline Stachys officinalis & $3 / 0.7$ & 0/- & $2 / 1$ & $11 / 3.2$ & $8 / 4.5$ & Grassland \\
\hline Stellaria media & $\underline{4 / 2.1}$ & 0/- & 0/- & 0/- & 0/- & Ruderal \\
\hline Taraxacum sect. Ruderalia & $18 / 2$ & $\underline{62 / 4.4}$ & $37 / 2.8$ & $25 / 1.1$ & $16 / 1$ & Ruderal \\
\hline Teucrium chamaedrys & $3 / 3.8$ & $2 / 0.8$ & $43 / 3.8$ & $44 / 1.2$ & $\underline{56 / 3.7}$ & Grassland \\
\hline Thlaspi perfoliatum & 0/- & 0/- & 0/- & 0/- & $\underline{3 / 0.5}$ & Grassland \\
\hline Thymus preacox & $0 /-$ & 0/- & $0 /-$ & $2 / 0.5$ & $\underline{9 / 1.3}$ & Grassland \\
\hline Thymus pulegioides & $0 /-$ & $4 / 21.5$ & $5 / 2.4$ & $4 / 1.6$ & $23 / 1.5$ & Grassland \\
\hline Torilis japonica & 0/- & 7/1.1 & $3 / 0.7$ & 0/- & $0 /-$ & Ruderal \\
\hline Tragopogon pratensis & 0/- & $0 /-$ & $\underline{6 / 1.2}$ & $0 /-$ & $2 / 0.5$ & Meadow \\
\hline Trifolium dubium & 0/- & $0 /-$ & $\underline{10 / 2}$ & $0 /-$ & 0/- & Ruderal \\
\hline Trifolium montanum & 0/- & 0/- & 0/- & $0 /-$ & $\underline{6 / 1.8}$ & Grassland \\
\hline Trifolium repens & 0/- & $\underline{6 / 1.1}$ & $2 / 2.8$ & $0 /-$ & $1 / 0.5$ & Meadow \\
\hline Trisetum flavencens & $0 /-$ & $2 / 0.8$ & $\underline{19 / 5.1}$ & $0 /-$ & $4 / 5.6$ & Meadow \\
\hline Verbascum thapsus & $0 /-$ & $\underline{5 / 1}$ & 0/- & $0 /-$ & 0/- & Ruderal \\
\hline Veronica arvensis & 0/- & $6 / 0.8$ & $0 /-$ & $0 /-$ & $\underline{8 / 0.5}$ & Ruderal \\
\hline Veronica officinalis & 0/- & $\underline{10 / 1.8}$ & $1 / 1$ & $0 /-$ & $0 /-$ & Grassland \\
\hline Vicia cracca & 0/- & $\underline{5 / 0.6}$ & $1 / 0.5$ & $0 /-$ & 0/- & Ruderal \\
\hline Vicia sativa & 0/- & $4 / 0.9$ & 0/- & $0 /-$ & $\underline{10 / 0.7}$ & Ruderal \\
\hline Vicia sepium & $\underline{2 / 0.8}$ & 0/- & 0/- & 0/- & 0/- & Edge \\
\hline Viola hirta & $12 / 1$ & $62 / 2.5$ & $71 / 1.8$ & $80 / 2.3$ & $55 / 2$ & Edge \\
\hline
\end{tabular}

